\title{
Comparison of communication skill between railroad crossing guards
}

\author{
Dhina Setyo Oktaria \\ Politeknik Perkeretaapian Indonesia, Madiun, Indonesia
}

\begin{abstract}
Railroad Crossing Guard, commonly known as Penjaga Perlintasan Kereta Api (PJL), has a task in safeguarding the railroad crossing. In carrying out their task, PJL needs to communicate with other PJL and Train Dispatcher (PPKA) in the working area. Therefore, communication plays a critical role in the safety aspect. In 1987, the worst train accident happened in Indonesia's history of railways, which was caused by miscommunication as the main factor of this accident. This study aims to improve communication skills for all PJL staff in Indonesia to achieve safety at railroad crossings. This study used primer data obtained from questionnaires distributed to 97 PJL individuals under Transportation Department (Dishub) and 97 PJL individuals under PT KAPM. Nowadays, PJL in Indonesia is under Dishub and PT KAPM. The sample was determined using Lemeshow's formula because the number of subjects from previous studies was unknown or data on the exact number of all PJL in Indonesia was unavailable. Data were analyzed using descriptive and inferential statistics with the Mann Whitney U test. PJL under the Transportation Agency and PJL under PT KAPM did not understand the importance of recording communication when maintaining a railroad crossing. The Mann-Whitney U test inferential statistics analysis indicates that the hypothesis was accepted, namely differences in communication skills between PJL under Dishub and PJL under PT. KAPM. The average ranking value was obtained from the total comparison value of all variables from PJL of Dushub and PJL of PT KAPM, with the Mann Whitney U test results was 79.90 and the average ranking value of PJL under PT. KAPM was 113.10.
\end{abstract}

Keywords: PJL; transportation agency; PT KAPM; communication; railway

\section{Perbandingan kemampuan komunikasi penjaga perlintasan sebidang}

\begin{abstract}
ABSTRAK
Penjaga Perlintasan Kereta api atau yang disebut PJL adalah orang yang menjaga perlintasan kereta api. Dalam melaksanakan tugasnya seorang PJL perlu saling berkoordinasi dengan PJL lainnya dan PPKA di wilayah kerjanya. Komunikasi adalah hal yang penting terkait keselamatan. Tahun 1987 terjadi kecelakaan kereta api paling parah dalam sejarah perkeretaapian di Indonesia dimana salah satu unsur utama penyebabnya adalah terjadinya kesalahan dalam berkomunikasi. Tujuan dari penelitian ini agar dapat menjadi masukan terkait peningkatan kemampuan berkomunikasi bagi seluruh PJL di Indonesia untuk mencapai keselamatan di perlintasan sebidang. Penelitian menggunakan data primer berupa kuesioner yang disebarkan kepada 97 orang PJL di bawah Dinas Perhubungan (Dishub) dan 97orang PJL di bawah PT KAPM. Untuk saat ini PJL yang ada di Indonesia berada di bawah Dishub dan di bawah PT KAPM. Penentuan sampel menggunakan rumus dari Lemeshow dikarenakan belum diketahui jumlah subyek dari penelitian sebelumnya ataupun tidak terdapat data jumlah pasti seluruh PJL di Indonesia. Analisa data menggunakan statistik deskriktif dan statistik inferensial dengan menggunakan Uji Mann Whitney U. PJL di bawah Dishub maupun PJL di bawah PT KAPM masih kurang paham arti pentingnya komunikasi yang dilakukan selama menjalankan tugas menjaga perlintasan sebidang kereta api harus di rekam. Sedangkan analisis dengan statistik inferensial dengan menggunakan uji Mann Whitney U diperolah hasil akhir hipotesis diterima, yaitu terdapat perbedaan kemampuan dalam berkomunikasi antara PJL di bawah Dishub dengan PJL di bawah PT. KAPM. Nilai rangking rata-rata adalah nilai total perbandingan semua variabel dari PJL dari Dushub dan PJL PT KAPM dengan uji mann whitney U sebesar 79.90 dan nilai rangking ratarata PJL di bawah PT. KAPM adalah sebesar 113.10.
\end{abstract}

Kata-Kata kunci: PJL; Dishub; PT KAPM; komunikasi; perkeretaapian

Korespondensi: Dhina Setyo Oktaria, SH., M.Sc., Indonesian Railway Polytechnic, Jl Tirta Raya Kota Madiun,Email: dhina@ppi.ac.id 


\section{INTRODUCTION}

The ability of human resources is one of the crucial factors to ensure safety in the railway. In fact, a human becomes one of contributing factors to accidents in a series of events. Based on data from KNKT from 2010 until 2016, several factors contributed to railway accidents, including $41 \%$ from infrastructure, 33\% from humans, $19 \%$ from facilities, and 7\% from operational (Komite \& Perkeretaapian, 2016). Therefore, it is crucial to develop human competencies in their profession-professional means fulfilling the elements of having knowledge, skills, and abilities. In performance determination theory, knowledge is directly proportional to motivation; the higher the knowledge possessed by the employee, the higher his motivation to have good performance so that he will be able to achieve the goals determined by a company where he works. Meanwhile, the determination of performance based on expertise depends on the ability of each employee to choose a work method that can increase the productivity of the employee's performance. When employees increase their productivity, it will be followed by an enhancement in work efficiency and speed of information processing and a decrease in error occurrence. The company expects that each employee has their own abilities to fulfill the things mentioned above because the company has conducted a series of recruitment tests and provided training and learning in the form of knowledge before being accepted, in order to carry out pre-service education following the expertise required by the company (Surya, Astuti, \& Susilo, 2014).

In the national railway seminar, Tatang Kurniadi, as head of KNKT, conveyed the factors that might lead to accidents, including unsafe behavior and unsafe conditions. In such circumstances, it is necessary to find the targets that must be identified and then take action to reduce the occurrence and turn it into safety behavior and conditions as planned and gradually through a safety program. Safety behavior and conditions can be applied in many ways, such as through educational activities, eligibility, changing facilities and infrastructure, supervision, certification, or fines or criminal penalties. Human is an asset that cannot be calculated or directly observed physically; it must be built to have a deep awareness of safety in the railway sector. Based on the results of the investigation carried out by NTSC, it found out the general conditions that could lead to transportation accidents that affected the occurrence of accidents. It decreased levels of safety, including safety culture, law enforcement, and regulations that are less consistent or incomplete rules regarding safety, inadequate training, there is no rewards or punishments and regulations that need to be replaced or adapted to the times, infrastructure, and transportation facilities that are not following the demands and do not meet the feasibility standards and technical requirements, and lack of coordination and responsibility between instances to maintain safety. (Kurniadi, 2010). A railroad crossing guard, or after this abbreviated as PJL, is a person responsible for guarding railroad crossings. PJL needs to coordinate with other PJL and PPKA in their working area to carry out their duties. Coordination is needed to ensure the continuity of train traffic from the preparation of the departure station, the trip at each station, and the final station. It is necessary to communicate between PPKA and PJL in their respective working areas that railroad facilities pass. In this coordination, interpersonal communication is needed where effectiveness is supported by several personal and individual factors who communicate, including trust, supportive attitude, and open attitude. (Ruliana \& Lestari, 2019). Communication is a crucial element; on October 19, 1987, there was the worst train accident occurred in the history of railways that occurred in Bintaro, Indonesia, which caused more than 150 people to die, and based on the investigation, one of the main factors was a miscommunication between PPKA personnel, machinists and level crossing guard (Nugraheni, 2021). According to the $\mathrm{KBBI}$, communication is sending and receiving messages or news between two or more people so that the intended message can be understood; (Setiawan, n.d.).

Effective communication can only be achieved if a supervisor/ manager in the organization can find out, prevent, and correct mistakes made by their subordinates. They send the message to their subordinates without causing unequal views in receiving information or orders to prevent unsatisfactory results. (Ningrum, 2013). 
Stimulus in delivery and conveying messages is very influential in communication. Good message management is emphasized in communication. Knowing the individuals involved in communication is very important to manage the message correctly. The similarity in language, knowledge, insights, and even the context in the message can influence the expected feedback (Devito, 2017). Communication will be effective if the words contain denotative meaning (the word has the same meaning as a dictionary and is generally accepted by most people who have similarities in culture and language). If the communicator is forced to use connotative words, he/she should explain the real purpose to prevent misinterpretation. (Nurhadi \& Kurniawan, 2017)there are some requirements in the effective communication so the message can result in feedback from communicant, namely: 1 .

If PJL personnel did negligence when carrying out their duty, they would get an administrative sanction started from receiving a warning letter, the certificate gets freeze and revoked. They can be subject to criminal sanctions when they are proven to have committed an unlawful act and made a mistake (Mahmud, 2020). Railway crossings are passed by trains and vehicles; therefore, two regulations are applied, including Law 23 of 2007 concerning Railways and Law No. 22 of 2009 concerning Road Traffic. Referring to accident data at railway crossings, from 2015 to June 7, 2019, it was recorded that there were 1,470 accidents with 179 incidents at guarded railway crossings and 1,291 at unguarded railway crossings (Sianipar, 2019). Based on data from the Ministry of Transportation, in 2018, there were 395 accidents with several fatalities. there were 245 people with minor injuries, serious injuries, and deaths, and based on data from PT KAI during 2019, there were 260 accidents with 76 fatalities. (Hariyanto, 2019).

Based on Minister Regulation No. 94 of 2018, many railway crossings have not been disciplined and cause frequent accidents at railway crossings. Therefore, regulations are needed to provide certainty for safety during traveling with a train and people who pass through railways crossings and provide a legal umbrella to manage the railway crossings. Safety between railways crossings and roads requires cooperation and coordination between all relevant parties; for example, the Transportation Agency is responsible for installing traffic signs and public street lighting equipment, while the railway facility operator is responsible for equipped railroad gates with guard posts. The Department of Public Works Services is responsible for repairing the railroad crossing using asphalt because this area is mainly passed by non-motorized vehicles, motorcycles, and light vehicles. The police are authorized to conduct law enforcement. (Budiharjo \& Yunarto, 2019)

In addition, the preamble/explanation of Minister Regulation No. 45 of 2018 (Ministry of Transportation of the Republic Indonesia, 2018). Described that the communications between PJL should meet the operating requirements, they must be able to call and/ or be called on both communicating parties, able to communicate in two directions; the information received must be understandable and clear in each communication; every conversation in communication must be recorded, and communication must be equipped with a protection system. Generating a pleasant and comfortable communication pattern can be carried out through a simple communication process with several communication media, not only with a direct face-to-face communication process but also media can be used as an option to build effective communication. (Triwardhani, Trigartanti, Rachmawati, \& Putra, 2020). In Minister Regulation No. 19 of 2011, PJL personnel must meet standards competency and skill, including operating railway telecommunications equipment. A person can be said to be competent if he can carry out their role and task, as well as they also have skills and knowledge and be supported by an attitude following the demands of the job. So, it can be concluded that professionalism comes from competence in the form of skills or knowledge in a particular field, so it can be stated that competence is the ability to carry out obligations or work based on knowledge, skills and is influenced by attitudes which become individual characteristic.

Based on data from Freshtrendx (Freshtrendx, 2017) taken from 2015 - 2016, there were 416 districts and 98 cities in Indonesia. In total, there were 514 districts and cities in Indonesia. Based on this, it can be concluded that there were 416 district-level Transportation 
Offices in Indonesia, 98 City Transportation Offices, and 34 Provincial Transportation Offices. PT KA Properti Manajemen or KAPM (KAPM, 2021) is a subsidiary of PT Kereta Api Indonesia (Persero). PT KAPM was established in 2009 and had several businesses, including the core business in the property sector. It is intended to encourage PT KAPM to optimize its capital and property management, which belongs to PT Kereta Api Indonesia (Persero) or other parties, by applying the principles that a Limited Liability Company must possess in order to meet the best quality standards. PT KAPM also carried out other businesses, such as construction and trading. Meanwhile, the railroad crossing guard is part of another business in the form of human resource assets, such as employees who work at PT KAPM and are placed at the JPL post to guard railroad crossings.

Based on the information mentioned above, the problem formulation can be drawn, which is whether there is a difference in communication ability between PJL from Dishub and PJL from PT. KAPM? Does the communication ability between PJL under Dishub and PJL under PT KAPM comply with the provisions of the legislation?

With Hypothesis Ho: it is suspected that there were differences in communication ability between PJL under Dishub with PJL under PT. KAPM and Ha: it is suspected that there is no difference in communication ability between PJL under Dishub and PJL under PT. KAPM.

\section{RESEARCH METHODS}

This study used a quantitative method, which uses statistical calculations and has basic assumptions. Quantitative research describes or explains a problem whose results can be generalized. The researcher must be objective and separate his subjectivity from the data. (Hariwijaya, 2007).

The sample in this study was all PJL that worked in Indonesia compared to $100 \%$ PJL from the Department of Transportation and $100 \%$ PJL from PT KAPM. The sample was taken using sampling technique with formula from Lemeshow (Kutner, Nachtsheim, Neter, \& $\mathrm{Li}, 2005)$ as follows:

$$
\mathrm{N}=\underline{\mathrm{Z}} \underline{\underline{2}} \underline{\mathrm{x}} 0,5(1-\mathrm{P})
$$

d

Explanation :

$\mathrm{N}$ : Number of samples

$\mathrm{Z}: 95 \%$ confidence level $=1.96$ (two tails)

P: Proportion of previous research subjects

(if not use 0.5)

$\mathrm{d}$ : level of precision $(10-90 \%)$

Explanation :

$\mathrm{N}$ : Number of samples

$\mathrm{Z}: 95 \%$ confidence level $=1.96$ (two tails)

P: Proportion of previous research subjects (if not use 0.5)

$\mathrm{d}$ : level of precision $(10-90 \%)$

This study uses a confidence level of $95 \%$ so that the value of $\mathrm{z}$ is 1.96 . This study used 0.5 and a precision level of $10 \%$, considering that the subject of previous research was unknown, and there was no data on the exact number of all PJL personnel in Indonesia from the Transportation Agency and PT KAPM. Following the above formula, the sample size obtained is:

$$
\mathrm{N}=1.962 \times 0.5(1-0.5)
$$$$
0.12
$$

$=96.4$ samples rounded up to 97

respondents

Considering that there were two different respondents, therefore researcher took 97 respondents for PJL from Dishub and 97 respondents for PJL from PT KAPM. Data were collected using a questionnaire distributed and filled out by PJL from Transportation Agency and PJL from PT KAPM. The questionnaire was equipped with a Likert scale, with a value between 1 to 3 . The scoring for each answer in the questionnaire is as follows table 1 .

The instrument in this study used two variables, namely the dependent variable and the independent variable (Hidayat, 2012). The dependent variable, or $Y$, is the communication between PJL, PPKA, and other PJL partners. Indicators of measurement are the knowledge, skills, and abilities of a PJL, which can be categorized into good, fair, and poor. The indicator to determine that the ability is reasonable, fair and poor, is arranged in Minister Regulation no.19 of 2011 Article 3 paragraph 2 point $d$, which states that a PJL must be able and proficient in operating railway telecommunications equipment. There are various types of railway telecommunications equipment, including telephone, rig, handy 
Table 1 Questionnaire Score

\begin{tabular}{ccc}
\hline No & Item Description & Score \\
\hline 1 & Good & 3 \\
2 & Fair & 2 \\
3 & Poor & 1 \\
\hline
\end{tabular}

Source: Researcher data, 2020

talky (HT), intercom, telephone, and rigs. Phone and HT, rig and HT, and clapper. Thus, the indicator is proficient in operating the various railway telecommunications equipment in communication (Kementerian Perhubungan, 2011).

In Minister Regulation no. 45 of 2018: Article 1 paragraph 6 states that the definition of railway telecommunications equipment is a facility for the operation of trains in order to convey information and or communication that is useful for operations, rail security, train safety, and the railway passenger service system installed on certain places both along the railway line and at the train station. Thus, the indicator is that crossing guard communication should meet the operational requirements in communication between PJL personnel or between PJL and PPKA. The communication must be two-way; namely, they can call and or be called so that the information received by either the PJL or PPKA is understandable and clear, then every conversation must be recorded and equipped with a protection system.

In addition, Minister Regulation no. 45 of 2018 Article 4 paragraph 2 states that telephones used in communication in train operation activities are also used for communication between PPKA and PJL related to training trips. The indicator is to understand the schedule of train trips that pass in their work area and also communication for the extraordinary train trips which did not list in the daily train schedule but is announced through Malka (Maklumat Perjalanan Kereta Api or Announcement of Railway Traveling) and WAM (Warta Maklumat or news announcements).

The independent variable or variable $\mathrm{X}$ in this study consists of:

X1: The communication tools of PJL are placed in the room, whether installed on the crossing guard table, which is easy to access with a sturdy structure,
X2: Communication should meet the minimum requirements, PJL should be able to call and/or be summoned,

X3: communication should meet the minimum requirements, PJL should be able to communicate in two directions,

X4: communication should meet the minimum requirements, that the information received must be understandable and clear,

X5:communication should meet the minimum requirement that every conversation must be recorded,

X6: communication should meet the requirements and has been equipped with a protection system,

X7: The shifts distributed between PJL affect the ability to communicate with railway crossing guards.

Data processing methods used validity and reliability tests to evaluate whether the questions from the questionnaire were valid and reliable. After the validity and reliability tests have been carried out, if the data is declared valid and reliable, the following action is to analyze the data with descriptive and inferential statistical analysis. The data processing process was processed by testing the average of two unpaired groups (independent sample T-test). A test can be carried out in a normality test and a homogeneity test. First, a normality test was carried out, and if it is found that the data is abnormal, then a homogeneity test is carried out, and it can be concluded that the data is homogeneous. The Mann-Whitney $\mathrm{U}$ test carried out the last test to evaluate the truth of the proposed hypothesis. The basis for decision-making with the Mann Whitney U test is the Asymp.Sig value $<0.05$ means that the hypothesis is accepted or the Asymp.Sig value is $>0.05$ means that the hypothesis is rejected.

\section{RESULTS AND DISCUSSIONS}

Before becoming a railroad crossing 
guard, the person must obtain education and training regarding railroad crossing guarding following Minister Regulation No. 19 of 2011 are participating in education and training in the form oflearning activities to increase knowledge, skills, and attitude. This is necessary to ensure the implementation of reliable transportation. Following the regulations, education and training providers are carried out by legal entities or educational and training institutions that have received accreditation from the Minister; or by the Directorate General of Railways. After PJL has attended education and training consisting of education for a total of $50 \mathrm{JP}$ with the material in the form of legal aspects of railroad crossings, emergency conditions, crossing gate operations, train slogans, and road traffic signs, train travel, tasks, and authority of crossing gate guards, occupational health and safety and work practices, so that prior PJL personnel did their role, they must be equipped with knowledge, skills, and abilities because they have high responsibilities. The questionnaire filled out by PJL from the Transportation Agency, or PT KAPM, was tested for validity and reliability for each questionnaire. The purpose of data analysis with validity testing is to determine the validity of the questionnaire. Considering that the number of respondents for each agency was 97 respondents with the same questionnaire question items, then according to the formula:

$\mathrm{df}=\mathrm{n}-2$ with $5 \%$ significance

$\mathrm{df}=97-2=95$, in table $\mathrm{r}$ with a significance of $5 \%$, it was obtained 0.206

Based on the data processing results using SPSS 25 with an $r$ table value of 0.206 , the following results were obtained: X1 Pearson correlation $0.530>0.206$, means it is valid, $\mathrm{X} 2$ Pearson correlation $0.688>0.206$, means it is valid, X3 Pearson correlation $0.627>0.2066$ means it is valid, X4 Pearson correlation 0.722 $>0.206$ means it is valid, X5 Pearson correlation $0.498>0.206$ then valid, X6 Pearson correlation $0.719>0.206$ then valid and X7 Pearson correlation $0.307>0.206$ means it is valid. Based on the results of data processing using SPSS 25 with a significant correlation value of 0.001, the following data obtained: X1, X2, X3, $\mathrm{X} 4, \mathrm{X} 5, \mathrm{X} 6$ and $\mathrm{X} 7$ significance (2-tailed) the value is $0.000<0.01$, means it is valid.

The reliability test to determine the consistency of the questionnaire is shown in
Table 2 Measurement of Questionnaire Reliability

\begin{tabular}{cc}
\hline Coefficient & Interval Relationship Level \\
\hline $0.000-0.199$ & Very low \\
$0.200-0.399$ & Low \\
$0.400-0.599$ & Medium \\
$0.600-0.799$ & Strong \\
$0.800-1,000$ & Very strong \\
\hline
\end{tabular}

Source: Table of questionnaire reliability measures, 2020

Table 3 Cronbach's Alpha

\begin{tabular}{cc}
\hline Cronbach's Alpha & Number of questions \\
\hline 0.704 & 8 \\
\hline
\end{tabular}

Source: Researcher data, 2020

the table for measuring the reliability of the questionnaire, table 2.

Based on the analysis results using SPSS 25 , it was found that Cronbach's Alpha was 0.704 from 8 questionnaire questions. The value of 0.704 was following the reliability table above is categorized as a strong relationship level, table 3.

Based on the results obtained from the validity and reliability tests above, it can be concluded that all question items in the questionnaire can be accepted because they met the valid and reliable elements. Thus, there is no need for question items that were not used. Analysis using descriptive statistics, table 4.

Based on the table above, the results show that the average age of PJLfrom Dishub was 28 years or three years younger than the average age of PJL from PT KAPM was 31 years. In terms of gender, $100 \%$ of PJL, either from Dishub or PT KAPM, were male. The average tenure of PJL from Dishub was 2.6 years, while PJL under PT KAPM was 5.3 years, the difference was 2.7 years. The communication tool used mainly by PJL from Dishub was HT, while PJL from PT KAPM used the telephone. On average, PJL from Dishub filled out questionnaires when carrying out their duties in shift one, and PJL from PT KAPM filled out questionnaires during shift 2. There was no significant difference between PJL from Dishub and PJL from PT 
Table 4 Table of Descriptive Statistics Results

\begin{tabular}{llll}
\hline No & Average value & PJL from Dishub & PJL from PT KAPM \\
\hline 1. & Age & 28,28 & 31,12 years \\
2. & Gender & Male & MAle \\
3. & Length of work & 2.67 & 5.37 years \\
4. & Communication tool & HT & telephone \\
5. & Shift & 1 & 2 \\
6. & PES communication with PPKA & 2,44 & 2,84 \\
7. & The communication device is installed on the & 2,67 \\
& crossing guard table, which is easy to reach & 2,72 \\
& and with a sturdy structure & & \\
8. & Communication can call and/or be called & 2.72 & 2,94 \\
9. & Can communicate both ways & 2,56 & 2,70 \\
10. & Information received must be clean and clear & 2,54 & 2,74 \\
11. & Every conversation must be recorded. & 1,76 & 2,35 \\
12. & Equipped With Protection System & 2,31 & 2,53 \\
13. & The division of picket shifts affects the ability & 2,58 & 2,62 \\
& to communicate PJL & \\
\hline
\end{tabular}

Source: Researcher data processing results, 2020

KAPM in answering the questionnaire about the communication devices installed on the crossing guard table, which is easily accessible and with a sturdy structure. The questionnaire results related to communication devices installed on the crossing guard desks that are easily accessible, and with a solid structure, able to communicate in two directions, the information received must be understandable and clear, equipped with a protection system, the distribution of shifts which could affect the ability to communicate, indicate that PJL from PT KAPM has an average value which is closer to 3 than the PJL from Dishub. Regarding recording Communications, the results show that the average value of PJL from Dishub was 1.76 and PJL from PT KAPM was 2.35. Even though according to the considerations/ explanation of Minister Regulation No. 45 of 2018, crossing guard communications at least meet operational requirements, one of which is every communication or every conversation must be recorded.

Analysis with inferential statistics on the comparison of communication skills between PJL officers from Dishub and PJL officers from PT KAPM. With the average test of two unpaired groups (independent sample T-test) in the form of a normality test. The resulting data is abnormal because the data is said to be normal if it meets the criteria with significance score (Sig) on the Kolomogrov-Smirnov $>$ the significance level (t.s) is 0.05. The results show that the significance score (Sig) for PES from Dishub was 0.000 , smaller than the significance level value of 0.05 . Likewise, PJL from PT. KAPM found that the significance score (Sig) is 0.000 , where this value is smaller than the significance level value of 0.05 . Then the homogeneity test was carried out, so if the PJL from Dishub and PJLfrom PT KAPM had the same variance, then the two groups were said to be homogeneous. The homogeneity test using SPSS 25 with data criteria will be considered homogeneous if the significance score (Sig) on the test table of homogeneity of variances $>$ significant level (ts), which is 0.05 . The results show that the significance score ( $\mathrm{Sig}$ ) is as follows: based on the mean, Sig was obtained 0.063, which value is more significant than 0.05 , which means it is homogeneous. Based on the median it was obtained Sig 0.068, which value is more significant than 0.05 , means it is homogeneous. Based on the median, which customized df, 
Table 5 Table Of Average Rank

\begin{tabular}{crrcc}
\hline & PJL & N & Mean & Total Rank \\
\hline Score & P J L & 97 & 79.90 & 7670.00 \\
& Dishub & & & \\
PJL PT & 97 & 113.10 & 10858.00 \\
KAPM & & & \\
Total & 194 & 0 & \\
\hline
\end{tabular}

Source: Results of research data, 2020

it was Sig of 0.068 , which value is more significant than 0.0 means it is homogenous. Based on the trimmed mean it was obtained Sig 0.081, which value is more significant than 0.05 , which means it is homogeneous. Based on the table above, the average ranking results show that PJL from Dishub was 79.90 and PJL from PT KAPM was 113.10. It shows that the ranking of PJL from PT KAPM is higher than that of PJL from Dishub (Table 5).

Based on the normality test and homogeneity test above, it is obtained that the data is abnormal and homogeneous, so the next step is to test the hypothesis using the MannWhitney U test, table 6.

Based on the table above, the decision was determined with the Mann Whitney $U$ test is if the Asymp. Sig value $<0.05$, then the hypothesis is accepted, and if the Asymp. Sig value $>0.05$, then the hypothesis is rejected. Based on the table above about ranking and about statistical tests using the Mann Whitney U test above, it can be concluded that the Asymp.Sig (2-tailed) value is $0.000<0.05$. So it can be concluded that "the hypothesis is accepted." Thus, there is a difference in the ability to communicate between PJL from Dishub and PJL from PT. KAPM. It can be observed from the results of the Mann Whitney Test, which show that the average ranking value for PJLfrom Dishub was 79.90, and the average ranking value for PJL from PT. KAPM was 113.10. The ability to communicate between PJL from the Department of Transportation and PJL from PT KAPM is according to the laws and regulations. Many community empowerment education and training programs implemented at the agency providing PES training and training are considered to improve the competencies possessed by a PJL to be more capable and skilled
Table 6 Mann Whitney U . Test Table

\begin{tabular}{cc}
\hline $\begin{array}{c}\text { Mann-Whitney } \\
\text { Test }\end{array}$ & 3014.000 \\
\hline Wilcoxon W & 7670.000 \\
Z & -4.176 \\
Asymp. Sig. (2-tailed) & .000 \\
\hline
\end{tabular}

a. Grouping Variable: PJL

Source: Researcher data processing results, 2020

in operating crossing gates, handling emergency conditions, and understanding the train motto. It is expected that with the development of skill competency of railroad crossing guards, the number of accidents at railroad crossings can be minimized and even avoided. (Rozaq, Adi, Wirawan, \& Prativi, 2019). Based on previous research on the "Adaptation Strategy of Railway Crossing Guards in the City of Surabaya," the results of the work rhythm of unofficial PJL and official PJL were different. This is because the process from the beginning is different, for example, recruitment, division of work schedules, working methods and equipment used, and income. The work rhythm is different because PJL is officially supervised and regulated by PT KAI which is the company that oversees PT. KAPM. Therefore official PJL has more capabilities than unofficial PJL (Seno, 2012). In addition, previous research found that PJL who did not meet the requirements and qualifications of skills could be observed from the certificate of proficiency and often neglected to carry out their duties; for example, PJLs were absent, or Children at railways crossings replaced PJLs. PT. KAI (Persero) DAOP IV Semarang encountered constraints in a limited number of crossing gate guards. Based on data from 705 crossings, 593 (84\%) crossings do not provide guards, including 334 official crossings and 95 illegal crossings. (Tiarma Lubis, 2017).

In-Law No. 23 of 2007 (Ministry of Transportation of the Republic Indonesia, 2007). article 80, paragraph 1 contains the implementation of the operation of the railway infrastructure; it must be carried out by officers who have met the requirements and qualifications of skills as evidenced by a certificate of proficiency. In addition, after obtaining a certificate of proficiency, a PJL is 
required to refresh his knowledge, abilities, and attitudes through refresher training. This refresher training activity can be carried out at least every two years to ensure safety in the job scope (Wirawan, Zulkarnain, Wahjono, \& Rozaq, 2019).

The person is interpreted as "officers," namely: Train Travel Regulatory Officers (PPKA), railway infrastructure maintenance personnel, railroad crossing guards. There are types of certificates for railroad crossing guards that must be possessed according to Article 2 paragraph 3 point $(d)$, which states that a PJL must be able and capable of operating railway telecommunications equipment. Likewise, in Minister Regulation No. 24 of 2015 (Ministry of Transportation of the Republic Indonesia, 2015) in article 16 paragraph, one that telecommunications equipment must at least meet the requirements consisting of PJL and communication tools used must be able to call/ or called. Then PES and the communication tools used must communicate in two directions. The communication is equipped with a selection facility to select calls, except for crossing guards/ PJL. Information on communication between PJL and PJL and PPKA, the information received must be understandable and clear. The established communication uses a power supply system, including principal, emergency, and backup power supplies. Communication tools must be equipped with a protection system. Finally, the established communication uses a voice recorder that records the entire conversation of train operations and alerts.

Based on the considerations/explanation of Minister Regulation No. 45 of 2018 (Ministry of Transportation of the Republic Indonesia, 2018). Explains that: minimum crossing guard communication meets operational requirements, including PJL and communication tools used must be able to call and/or be summoned; PES and the communication tools used must be able to communicate in two directions; communication between PJL officers or PJL and PPKA the information received must be clean and clear; Communication that exists between PJL officers or PJL and PPKA in every conversation must be recorded, and the existence of a protection system in the communication system was established.

Based on the processing results using descriptive statistics and the Mann Whitney
$\mathrm{U}$ test on the primary data of questionnaire towards PJL from the Transportation Agency and PJL from PT KAPM, it was found that from all the 5 (five) points that considered above, the position of PJL from Dishub is still under the PJL from PT KAPM. For communication regarding being able to call and/or being called either between PJL officers and PPKA or with other PJL officers in their working environment, it found that were some PJL mentioned that the communication is still at a fair stage. Likewise, the communication received must be understandable and clear for two-way communication, and the communication equipped with a protection system was at a fair stage. PJL has a high responsibility because it is related to the safety of other people, especially road users who cross railway crossings in their working area. Although in Law No. 22 of 2009 and Law No. 23 of 2007, it has been stated that train travel must take precedence over the highway, considering that train is crossing on its track and there must be a minimum distance of 400 meters for trains to apply braking until the train stop.

PJL, either from Dishub or PT KAPM, should have the ability to adapt to the characteristics of the trains that cross their working areas; for example, PJL in big cities or capitals are different from PJL that located in areas outside Java. PJL in big cities or capital areas on average trains crossing their working areas in the form of intercity trains or urban trains, while PJL outside Java trains crossing their working areas is mainly in the form of carriages transporting agricultural products and mines. Based on the research results related to the perception of PES, both from Dishub or PJL from PT KAPM in the Daop 1 Jakarta area during the covid-19 pandemic on traffic and PJL guard shifts, it affected the perception of PES by $14.4 \%$, which was during the Covid-19 pandemic. - The number of trains operating is reduced, but the shift is fixed (Oktaria, 2021). However, apart from this, there must still be communication between PJL and PJL or PJL and PPKA in their working area throughout the train journey from the origin station to the final station. Ordinary trains and facultative trains are listed in the train journey chart (Gapeka) and timetable, while special traveling trains (Perjalanan Luar Biasa or PLB) are listed in Malka, and special trains (Kereta Luar Biasa or 
KLB) are listed in WAM.

Available or a bell ringer when the train will depart from the station. Understanding that there is a PLB/KLB running on one day or for a certain number of days is known based on written and verbal notification from the head of the railroad resort concerned, and operationally it is also known based on a notification from one of the PPKA who is from the departure station via telephone telecommunications equipment. Problems will arise if the communication tool (chime) from the PPKA is disturbed and has not been detected early; this requires the PJL to be always ready and alert and pay attention to the arrival of trains from upstream or downstream (right or left side). Although there are many types of tools to communicate, PJL still has to be able to read communication with PPKA by using a communication tool in the form of a chime; this is because it is following the competencies that a PJL must have if he is in an emergency where The modern communication tool has a possibility meet technical problems so that it can use a communication tool from the sound of a chime. Across the work area, the legislation requires that communication between PJL or PJL and PPKA be recorded. Besides being required to be able to communicate, a PJL must have the ability to understand the duration that is needed for a train to travel across its working area, the hours of regular trains crossing its working area, and preparations for PLB/KLB trains that will pass through its working area. In addition, points that must be considered, especially in the communication section, every conversation must be recorded, for PJL under Dishub, it is still in the less to sufficient stage, and for PJL under PT KAPM, it is also still in the quiet stage leading to a good stage. In communicating, two basics must be considered, namely the communication is not private or not confidential anymore, among others, the communication is not private or confidential because of the desire or approval of each party communicating and secondly because of orders based on statutory regulations (Josua Sitompul, SH, 2014).

Records of communication between PJL or PJL and PPKA can be used as evidence because it is managed by law and must be carried out; even if it is not ordered by law, then it is included in wiretapping. In addition, recordings at the time of communication can also be used as evidence of an accident at a railway crossing or a train accident at the railroad crossing. Based on the information above, it is following laws and regulations so that it can be used as a recommendation so that communication is established in every discussion between PJL and PJL with PPKA during education and training or during refresher technical guidance for PJL throughout Indonesia organized by the Directorate General of Railways of the Ministry of Transportation which all PJL must follow in Indonesia, either from the Transportation Agency or PT KAPM, at least once every two years.

\section{CONCLUSION}

Based on the results of this study, it can be concluded that the communication skills between PJL from PT KAPM have a higher average score than PJL from Dishub in terms of the duration of work as PJL, ability to coordinate in communicating with PPKA, communication tools installed on the desk crossings that are easily accessible and with a solid structure inside the JPL post, the ability to call and/or be called between PJL and PJI or PJL and PPKA, that help them to communicate in two directions, two-way communication, every conversation that occurs must be recorded and completed with a protection system, and It is shown that shift distribution will affect the ability to communicate. PJL from Dishub is superior in age, with an average age of 3 years younger than PJL from PT KAPM. The similarity between PJL from Dishub and PJL from PT KAPM is that the gender is $100 \%$ male. The questionnaires were analyzed using inferential statistics, the Mann-Whitney U Test. The results show that the initial hypothesis or Ho was accepted, meaning that there was a difference in ability between PJL from Dishub with the average ranking value of 113, 10 and PJL from PT KAPM with an average rating value of 79.90 .

The ability to communicate between PJL from Dishub and PJL from PT KAPM follows the laws and regulations, but they need to record the conversations. Based on study results, it found that most of personnel PJL from Dishub and PJL from PT KAPM mentioned that they had not recorded their communication, which 
is not following; therefore, it is necessary to carry out technical guidance, training, and socialization intensively to all PJL in Indonesia, including the need to record every conversation when communicating and it is necessary to pay attention to support facilities, infrastructure, and professional personnel to collaborate without distinguishing the agency related communication for PJL, as well as cooperation in communicating regardless the source of agency. Because, principally, the main objective that needs to be achieved is same, namely safety for road users at railway crossings.

\section{REFERENCES}

Budiharjo, A., \& Yunarto, I. F. (2019). Study on improving the safety of the crossroads of the grogol railway in the tegal regency. Jurnal Keselamatan Transportasi Jalan (Indonesian Journal of Road Safety), 6(2), 15-37. https://doi.org/10.46447/ktj.v6i2.30

Devito, J. A. (2017). Fifteenth edition the interpersonal communication book. (M. Barbieri, Ed.) (15th editi). Boston : Pearson Education, Inc., 2017.

Freshtrendx. (2017). List of names of provinces, Regencies and Cities in Indonesia.

Hariwijaya, M. (2007). Methodology and thesis and dissertation writing for social sciences and humanities. (R. A. P, Ed.). Publisher Paranama Ilmu.

Hariyanto, I. (2019). Ministry of transportation: 245 people become victims of railway accidents in 2018.

Josua Sitompul, SH, I. (2014). The law of recording conversations on cell phones.

KAPM, P. (2021). PT KAPM Profile.

Kementerian Perhubungan. Minister of Transportation Regulation No. 19 of 2011 Concerning Certificate of Skills for Railway Crossing Guards, Pub. L. No. PM 19 Tahun 2011 (2011). Indonesia: JDIH Ministry of Transportation.

Komite, K. S., \& Perkeretaapian, I. K. (2016). Data investigasikecelakaan perkeretaapian tahun 2010 - 2016 (Database KNKT, 31 Oktober 2016) (Vol. 2016).

Kurniadi, T. (2010). Introduction to the head of knkt on media release December 28, 2010 at the Nanggala Building, Ministry of Transportation.
Kutner, M. H., Nachtsheim, C. J., Neter, J., \& Li, W. (2005). Applied linear statistical models fifth edition. (B. Gordon, Ed.) (Fifth Edit). New-York McGraw-Hill Companies.

Mahmud. (2020). Railway crossing gate (case study at daop 8 Surabaya). Dinamika Scientific Journal of Law, 26 No 9, 11561166.

Ministry of Transportation of the Republic Indonesia. Law Number 23 of 2007 Concerning Railways, Pub. L. No. UU No. 23 Tahun 2007, the State Gazette of the Republic of Indonesia (2007). Indonesia: JDIH Ministry of Transportation.

Ministry of Transportation of the Republic Indonesia. Minister of Transportation Regulation Number 24 of 2015 concerning Railway Safety Standards(2015). Indonesia: JDIH Kementerian Perhubungan.

Ministry of Transportation of the Republic Indonesia. Ministry Regulation No. 45 of 2018 concerning Technical Requirements for Railway Telecommunication Equipment (2018). Indonesia: JDIH Kementerian Perhubungan.

Ningrum, M. E. (2013). The role of internal communication in the work environment. Journal of the Electrical and Aviation Industry (INDEPT) Nurtanio University Bandung, 3(1), 25-30.

Nugraheni, N. A. (2021). 34 Years of Bintaro Tragedy, Train Accident Kills More than 150 People. Tempo.

Nurhadi, Z. F., \& Kurniawan, A. W. (2017). The study of the effectiveness of messages in communication. Jurnal Komunikasi Hasil Pemikiran Dan Penelitian, 3(1), 90-95.

Oktaria, D. S. (2021). The effect of rail traffic and shift guards in the covid-19 pandemic era on the perception of railroad crossing guards (pjl) in the operational area (daop) 1 Jakarta. Jurnal DinamikA, 2(1), 4566. https://doi.org/10.18326/dinamika. v2i1.45-66

Putri, N. E., Hakim, N., \& Yamin, M. (2016). Ecologicall footprint and biocapacity analysis for flooding prevention in South Sumatera. Jurnal Mimbar, 32(1), 58-64. Retrieved from https://ejournal.unisba. ac.id/index.php/mimbar/article/view/1729/ pdf

Rozaq, F., Adi, W. T., Wirawan, W. A., \& Prativi, 
A. (2019). Improving the competence of gatekeepers for railroad transportation in the city of Padang, West Sumatra, through the Community Empowerment Program. Prosiding SENIATI 2019, (February), 1-5.

Ruliana, P., \& Lestari, P. (2019). Communication theory (1st ed.). Depok: Rajawali Pers.

Setiawan, E. (2003). Indonesia Dictionary.

Sianipar, A. (2019). A study on the application of door technology with automatic fences and yellow boxes at level crossing. Journal of Land Transport Research, 22(1), 91102.

Surya, W. A., Astuti, E. S., \& Susilo, H. (2014). Pengaruh employee knowledge, skill, dan ability (ksa) terhadap penggunaan sistem informasi sumberdaya manusia. Jurnal Administrasi Bisnis (JAB), 8(1), 1-7.
Tiarma Lubis, E. W. (2017). Application of railway safety aspects at pt kai (persero) Daop IV Semarang. VisiKes Journal of Public Health, 16(1), 66-73.

Triwardhani, I. J., Trigartanti, W., Rachmawati, I., \& Putra, R. P. (2020). Teacher's strategy in building communication with parents of students at school. Jurnal Kajian Komunikasi, 8(1), 99. https://doi. org/10.24198/jkk.v8i1.23620

Wirawan, W. A., Zulkarnain, A., Wahjono, H., \& Rozaq, F. (2019). Community empowerment to improve the competence of crossing guards in the rail transport sector (Case Study in Baturaja, South Sumatra). Prosiding SENIATI 2019, (Februari), 347350. 